\title{
Anti-allergic effects of sesquiterpene lactones from the root of Aucklandia lappa Decne
}

\author{
CHANG-SEOB SEO ${ }^{1}$, HYE-SUN LIM ${ }^{1,2}$, SOO-JIN JEONG ${ }^{1}$ and HYEUN-KYOO SHIN ${ }^{1}$ \\ ${ }^{1}$ K-herb Research Center, Korea Institute of Oriental Medicine, Daejeon 34054; \\ ${ }^{2}$ Division of Allergy and Chronic Respiratory Diseases, Center for Biomedical Science, \\ National Institute of Health, Chungbuk 28159, Republic of Korea
}

Received December 9, 2014; Accepted September 1, 2015

DOI: $10.3892 / \mathrm{mmr} .2015 .4342$

\begin{abstract}
Aucklandia lappa Decne, a well-known traditional herbal medicine, is used for the treatment of asthma, rheumatism, coughs, tuberculosis and numerous other diseases. The present study evaluated the inhibitory effects of the three sesquiterpene lactones costunolide, dehydrocostus lactone, and alantolactone, isolated from a 70\% methanolic extract of Aucklandia lappa, on the expression of chemokine mRNA in $\mathrm{HaCaT}$ human keratinocyte cells. The cytotoxicities of the compounds on $\mathrm{HaCaT}$ cells were evaluated using a Cell Counting Kit8 assay. Furthermore, the inhibitory effects of the three compounds on chemokine expression in tumor necrosis factor (TNF)- $\alpha$ - and interferon (IFN)- $\gamma$-stimulated HaCaT cells were analyzed by reverse transcription-polymerase chain reaction analysis. Treatment with the compounds caused a significant reduction in the mRNA expression of a range of chemokines, including TARC/CCL17, MDC/CCL22, RANTES/CCL5 and interleukin- 8 in TNF- $\alpha$ and IFN- $\gamma$-stimulated HaCaT cells. The present study indicated that costunolide, dehydrocostus lactone and alantolactone may have the potential to be used for treating inflammatory skin disorders by suppressing chemokine expression.
\end{abstract}

\section{Introduction}

Aucklandiae Radix, the root of Aucklandia (A.) lappa Decne, syn. Saussurea lappa C.B. Clarke, which belongs to the family of Asteraceae, has been officially documented as 'Mokhyang' in the Korean Herbal Pharmacopoeia (1-4). A. lappa has been traditionally used to treat anorexia, nausea and abdominal pain (5). Several biological properties of A. lappa, have been confirmed by scientific studies, including its anti-oxidative (6),

Correspondence to: Dr Hyeun-Kyoo Shin, K-herb Research Center, Korea Institute of Oriental Medicine, Daejeon 34054, Republic of Korea

E-mail: hkshin@kiom.re.kr

Key words: anti-allergic effect, sesquiterpene lactones, costunolide, Aucklandia lappa Decne, dehydrocostus lactone, alantolactone anti-ulcer (7), anti-cancer (8), anti-viral (9) and hepatoprotective effects (10). A recent study by our group reported that A. lappa alleviates inflammatory chemokine production in $\mathrm{HaCaT}$ cells and house dust mite-induced atopic-like dermatitis in $\mathrm{Nc} / \mathrm{Nga}$ mice (11). In addition, it has been reported that sesquiterpene lactones from A. lappa have anti-cancer $(12,13)$, anti-ulcer $(14,15)$, and anti-inflammatory (16) effects. However, to the best of our knowledge, the effects of active components of A. lappa against atopic dermatitis have not yet been investigated. The present study investigated the effects of the three sesquiterpene lactones costunolide, dehydrocostus lactone and alantolactone on the expression of Thelper type 2 chemokines, which are essential factors in the development of atopic dermatitis, in $\mathrm{HaCaT}$ human keratinocytes.

\section{Materials and methods}

Preparation of $70 \%$ methanolic extract. The roots of A. lappa used in the present study were purchased from HMAX (Jecheon, Korea) in July 2009. The botanical identity of this sample was confirmed taxonomically by Professor Je-Hyun Lee (Department of Herbology, College of Korean Medicine, Dongguk University, Gyeongju, Republic of Korea). A voucher specimen (no. 2009-KIOM62) has been deposited at the Herbal Medicine Formulation Research Group (K-Herb Research Center, Korea Institute of Oriental Medicine, Daejeon, Republic of Korea). Dried roots of A. lappa $(100 \mathrm{~g})$ were extracted three times with $70 \%$ (v/v) methanol (1 1) (JT Baker, Phillipsburg, NJ, USA) for 90 min with heating under reflux. The extracted solution was filtered through filter paper and the solvent was evaporated at $40^{\circ} \mathrm{C}$ using a Büchi R-210 rotary evaporator (Büchi, Flawil, Switzerland) under vacuum to dryness, followed by freeze-drying (PVTFD10R; IlShinBioBase Co., Ltd., Dongducheon, Korea). The yield of the freeze-dried $70 \%$ methanolic extract obtained was $28.57 \%$ (28.57 g).

High-performance liquid chromatography (HPLC) analysis. Reference compounds costunolide, dehydrocostus lactone and alantolactone were purchased from ChemFaces (Wuhan, China). The purities of the three sesquiterpene lactones were $\geq 98.0 \%$ according to HPLC analysis. HPLC-grade solvents methanol, acetonitrile and water were obtained from JT 
A

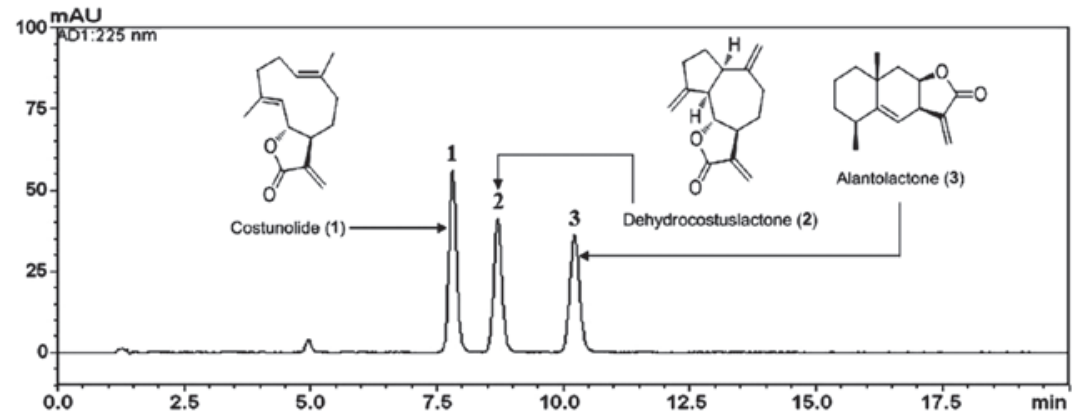

B

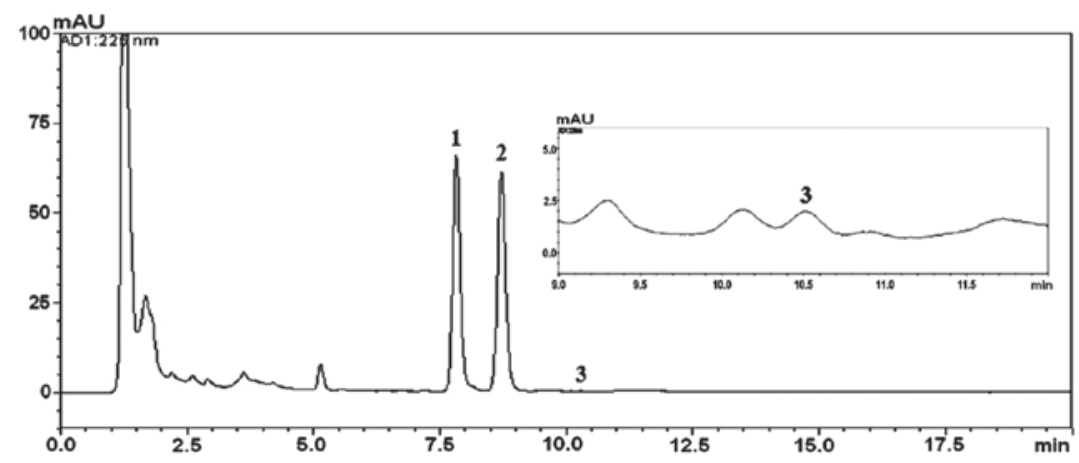

Figure 1. High performance liquid chromatograms of (A) standard solution and (B) Aucklandia lappa extract.

Baker. Glacial acetic acid (analytical grade) was purchased from Merck KGaA (Darmstadt, Germany). The sample was analyzed using a Shimadzu Prominence LC-20A series HPLC apparatus (Shimadzu Co., Kyoto, Japan) consisting of a solvent delivery unit (no. LC-20AT), on-line degasser (no. DGU-20A3), column oven (no. CTO-20A), auto sample injector (no. SIL-20AC) and PDA detector (no. SPD-M20A). Data were collected and processed using LCsolution software (version 1.24; Shimadzu Co.). The stationary phase used for the separation of the compounds was a reverse-phase SunFire ${ }^{\mathrm{TM}} \mathrm{C}_{18}$ analytical column (Waters, Milford, MA, USA; $150 \times 4.6 \mathrm{~mm}$ and $5 \mu \mathrm{m}$ particle size). The mobile phase was composed of water (A) and acetonitrile (B) with isocratic elution (i.e., $40 \% \mathrm{~A}$ and $60 \% \mathrm{~B}$ ). The flow rate was $1.0 \mathrm{ml} / \mathrm{min}$, the column temperature was maintained at $35^{\circ} \mathrm{C}$, and the injection volume was $10 \mu \mathrm{l}$. The detection wavelength for quantification covered the range of 190-400 $\mathrm{nm}$ and recorded at $225 \mathrm{~nm}$. To prepare the stock solutions, reference compounds were accurately weighed and dissolved in methanol to a concentration of $1.0 \mathrm{mg} / \mathrm{ml}$; the samples were stored below $4^{\circ} \mathrm{C}$. The concentration ranges of test samples for the generation of calibration curves were 1.56-200.00, 2.34-300.00 and 0.23-30.00 $\mu \mathrm{g} / \mathrm{ml}$ for costunolide, dehydrocostus lactone and alantolactone, respectively. For HPLC analysis of the $70 \%$ methanolic extract, $20 \mathrm{mg}$ extracted solid was dissolved in $10 \mathrm{ml} 70 \%$ methanol and dissolved by sonication for $30 \mathrm{~min}$. The solution was filtered through a $0.2-\mu \mathrm{m}$ membrane filter (Woongki Science, Seoul, Korea) prior to injection into the HPLC instrument.

Cell culture. The HaCaT human keratinocyte cell line was obtained from CLS Cell Lines Service GmbH (Eppelheim, Baden-Württemberg, Germany). The HaCaT cells were cultured in Dulbecco's modified Eagle's medium (DMEM,
Gibco-BRL, Invitrogen Life Technologies, Inc., Carlsbad, CA, USA) supplemented with $10 \%$ heat-inactivated fetal bovine serum (FBS; Gibco-BRL), penicillin (100 $\mu \mathrm{g} / \mathrm{ml}$; Gibco-BRL) and streptomycin $(100 \mu \mathrm{g} / \mathrm{ml}$; Gibco-BRL) in an incubator containing $5 \% \mathrm{CO}_{2}$ at $37^{\circ} \mathrm{C}$.

Cytotoxicity assay. Cell viability was evaluated using a Cell Counting Kit-8 (CCK-8; Dojindo, Kumamoto, Japan) following the manufacturer's instructions. HaCaT cells $\left(1 \times 10^{3}\right.$ cells/well) were incubated in 96-well plates with costunolide or dehydrocostus lactone at $0,1.25,2.5,5$ or $10 \mu \mathrm{M}$ or with alantolactone at $0,0.625,1.25,2.5$ or $5 \mu \mathrm{M}$ for $24 \mathrm{~h}$. CCK-8 reagent was added to each well and cells were incubated for an additional $4 \mathrm{~h}$. The absorbance was measured at $450 \mathrm{~nm}$ using a Benchmark plus microplate reader (Bio-Rad Laboratories, Hercules, CA, USA). The percentage of viable cells was calculated as follows: Cell viability $(\%)=($ mean absorbance in test wells/mean absorbance in untreated control well) $\mathrm{x} 100$.

Reverse transcription quantitative polymerase chain reaction (RT-qPCR). Total RNA was extracted using TRIzol reagent according to the manufacturer's instructions (Invitrogen Life Technologies, Inc.). HaCaT cells $\left(1 \times 10^{6}\right.$ cells/well) were cultured to $80-90 \%$ confluency in 6 -well plates. When the cells reached confluence, the cells were washed and treated with costunolide, dehydrocostus lactone or alantolactone in $1 \mathrm{ml}$ serum-free medium (Gibco-BRL) supplemented with tumor necrosis factor (TNF)- $\alpha$ and interferon (IFN)- $\gamma$ (each $10 \mathrm{ng} / \mathrm{ml}$; R\&D Systems Inc., Minneapolis, MN, USA) for 24 h. Silymarin (Sigma-Aldrich Inc., St. Louis, MO) was used as a positive control drug. Total RNA $(1 \mu \mathrm{g})$ was then converted into cDNA using an iScript cDNA Synthesis kit (Bio-Rad Laboratories, Inc.) containing oligo-dT primers. 
A

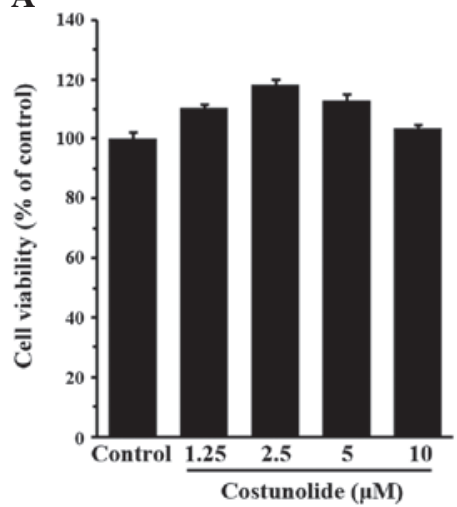

B

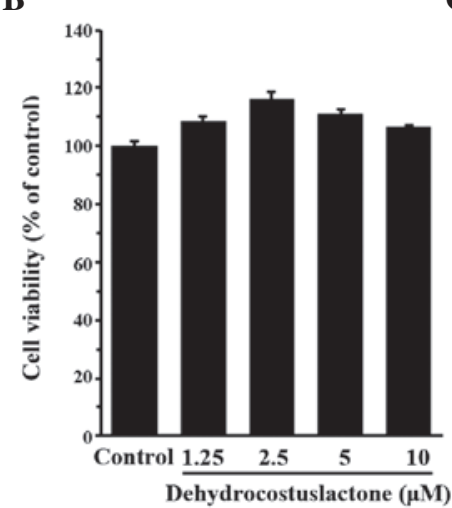

$\mathbf{C}$

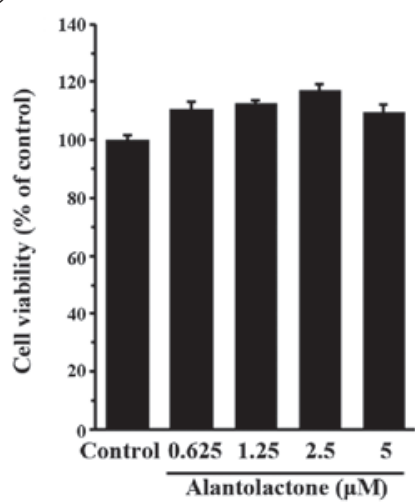

Figure 2. Cytotoxicity of the components of Aucklandia lappa extract on HaCaT cells. Cells were seeded onto 96-well plates and treated with various concentrations of the components of Aucklandia lappa extract for $24 \mathrm{~h}$. (A) Costunolide, (B) dehydrocostus lactone and (C) alantolactone. Cell viability was assessed using a Cell Counting kit- 8 assay. Values are expressed as the mean \pm standard error of the mean of three independent experiments.

A

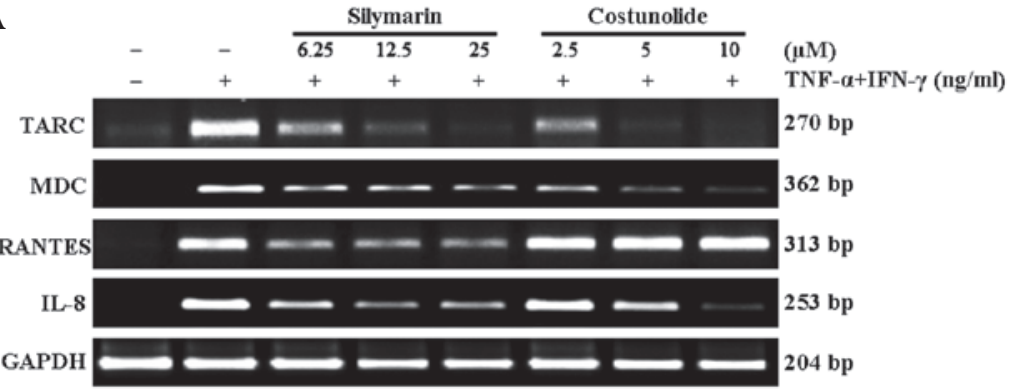

B
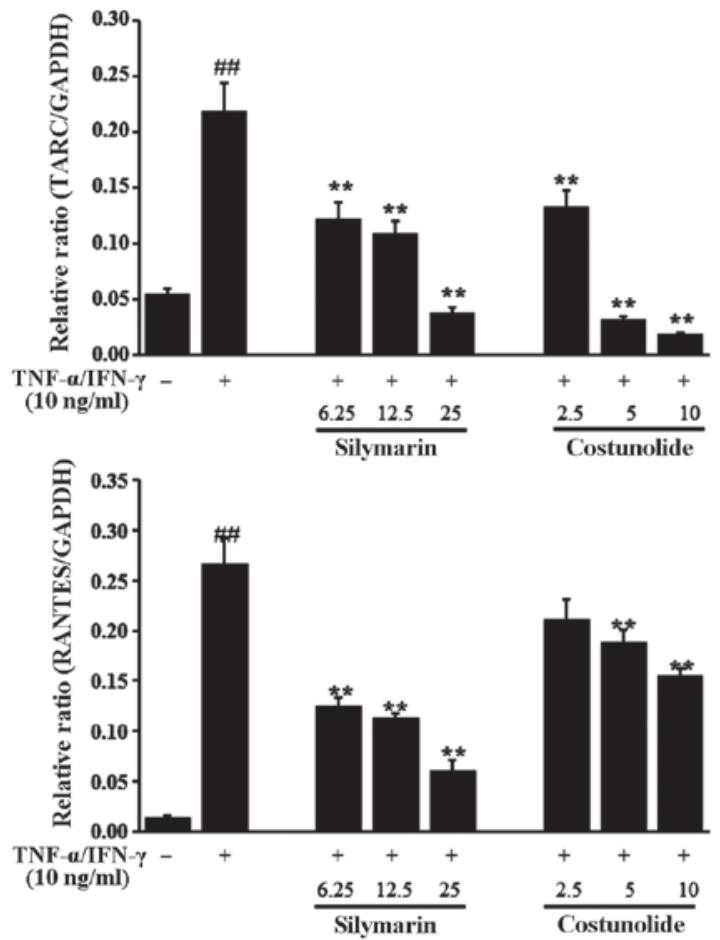
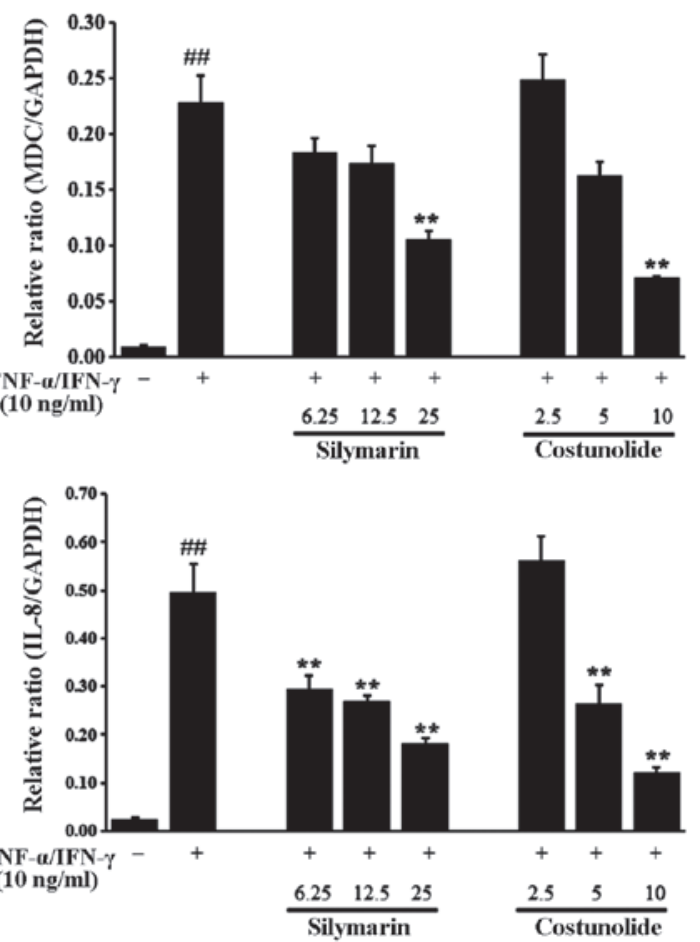

Figure 3. Effect of costunolide on TNF- $\alpha$ - and IFN- $\gamma$-stimulated expression of chemokine mRNA in HaCaT cells. (A) Reverse transcription PCR was performed to determine the mRNA expression levels of TARC, MDC, RANTES and IL-8. (B) Bar graphs representing the intensities of the PCR bands. Values are expressed as the mean \pm standard error of the mean of three independent experiments. ${ }^{\# \#} \mathrm{P}<0.01$ vs. vehicle control cells; ${ }^{* *} \mathrm{P}<0.01$ vs. TNF- $\alpha-$ and IFN- $\gamma$-stimulated cells. PCR, polymerase chain reaction. IFN, interferon; TNF, tumor necrosis factor.

Diethylpyrocarbonate-treated water was added to a final volume of $20 \mu \mathrm{l}$ followed by incubation at $42^{\circ} \mathrm{C}$ for $30 \mathrm{~min}$ using a Bio-Rad iCycler apparatus (Bio-Rad Laboratories,
Inc.). For PCR amplification, the following gene-specific primers were used: TARC forward, 5'-ACTGCTCCAGGG ATGCCATCGTTTTT-3' and reverse, 5'-ACAAGGGGA 

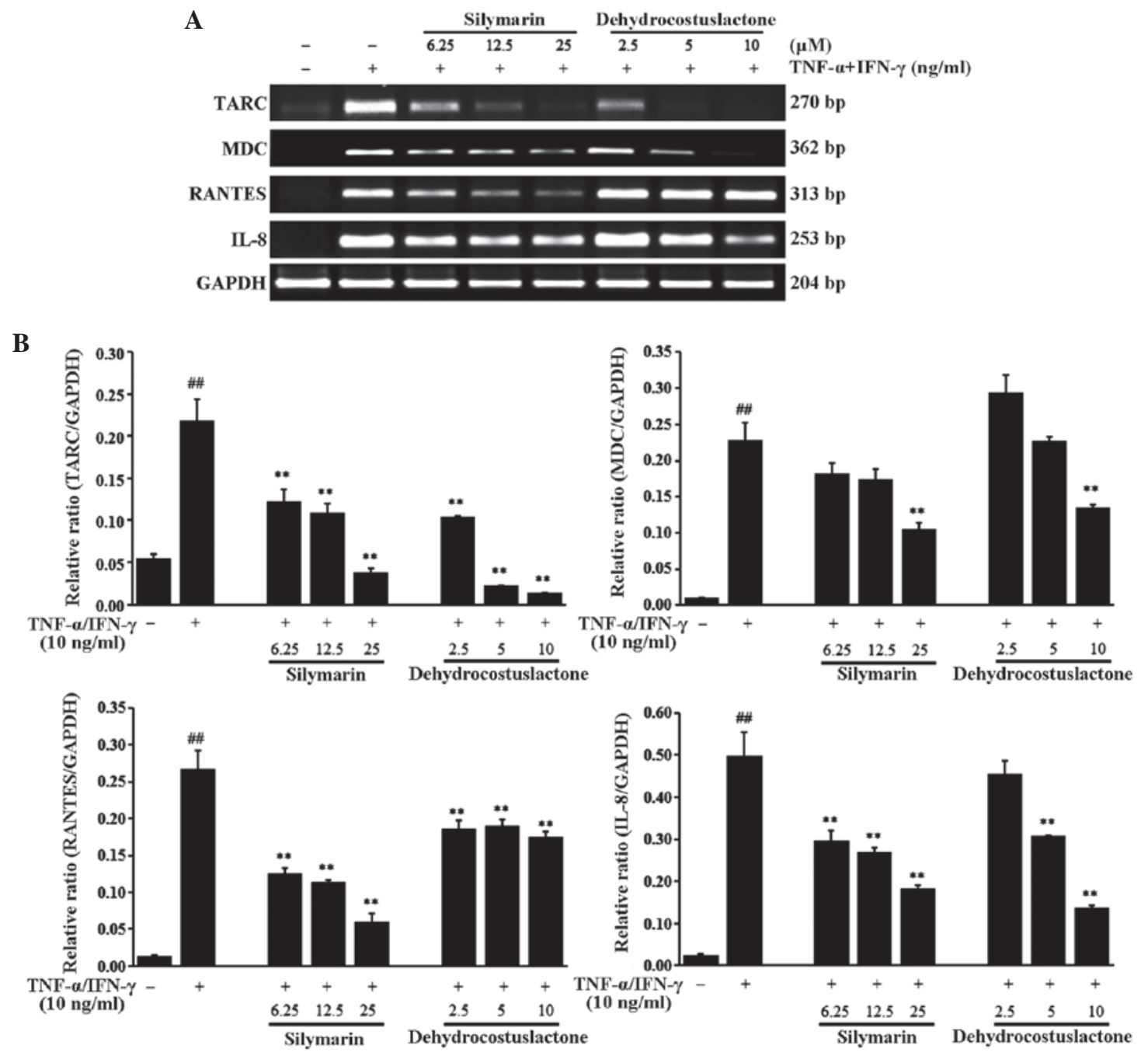

Figure 4. Effect of dehydrocostus lactone on TNF- $\alpha$ - and IFN- $\gamma$-stimulated expression of chemokine mRNA in HaCaT cells. (A) Reverse transcription PCR was performed to determine the mRNA levels of TARC, MDC, RANTES and IL-8. (B) Bar graphs representing the intensities of the PCR bands. Values are expressed as the mean \pm standard error of the mean of three independent experiments. ${ }^{\# /} \mathrm{P}<0.01 \mathrm{vs}$. vehicle control cells; ${ }^{* *} \mathrm{P}<0.01 \mathrm{vs}$. TNF- $\alpha$ - and IFN- $\gamma$-stimulated cells. PCR, polymerase chain reaction. IFN, interferon; TNF, tumor necrosis factor.

TGGGATCTCCCTCACTG-3'; MDC forward, 5'-AGGACA GAGCATGGCTCGCCTACAGA' and reverse, 5'-TAATGG CAGGGAGCTAGGGCTCCTGA-3'; RANTES forward, 5'-CCCCGTGCCGAGATCAAGGAGTATTT-3' and reverse, 5'-CGTCCAGCCTGGGGA AGGTTTTTGTA-3'; IL-8 forward, 5'-GTGGCTCTCTTGGCAGCCTTCCTGAT-3' and reverse, 5'-TCTCCACAACCCTCTGCACCCAGTTT-3'; and GAPDH forward, 5'-GTGATGGCATGGACTGTGGT-3' and reverse, 5'-AAGGGTCATCATCTCTGCCC-3'. The PCR reaction mixture contained $1 \mu \mathrm{l}$ cDNA and $1.56 \mu \mathrm{l} \gamma \mathrm{Taq}$ PCR master mix (cat. no. EBT-1014; Elpis Biotech, Inc., Daejeon, Korea), which contained $1.5 \mathrm{mM} \mathrm{MgCl}_{2}, 0.1 \mu \mathrm{M}$ of each forward and reverse primer and $7.44 \mu 1$ water in a final volume of $10 \mu \mathrm{l}$. The thermocycling program comprised initial denaturation at $94^{\circ} \mathrm{C}$ for $5 \mathrm{~min}$, followed by 25 cycles of denaturation at $94^{\circ} \mathrm{C}$ for $30 \mathrm{sec}$, annealing at $64^{\circ} \mathrm{C}$ for $1 \mathrm{~min}$, extension at $72^{\circ} \mathrm{C}$ for $1 \mathrm{~min} 30 \mathrm{sec}$ for all of the chemokines, and 25 cycles of denaturation at $94^{\circ} \mathrm{C}$ for $30 \mathrm{sec}$, annealing at $52^{\circ} \mathrm{C}$ for $1 \mathrm{~min}$, and extension at $72^{\circ} \mathrm{C}$ for $1 \mathrm{~min}$ $30 \mathrm{sec}$ for GAPDH. A final extension step was conducted at $72^{\circ} \mathrm{C}$ for $7 \mathrm{~min}$. The amplified products were separated by $1.5 \%$ agarose gel and visualized using Loading STAR staining (A750; DYNE Bio, Seongnam, Korea). The relative expression levels of TARC, MDC, RANTES and IL-8 mRNA were normalized to those of GAPDH mRNA using a Chemi-Doc Band Analysis system (Bio-Rad Laboratories, Inc.).

Statistical analysis. Values are expressed as the mean \pm standard error of the mean. All of the experiments were performed at least three times. One-way analysis of variance was used to detect significant differences between the control and treatment groups. Dunnett's test was used for multiple comparisons using GraphPad InStat version 3.10 (GraphPad Software Inc., La Jolla, CA, USA). $\mathrm{P}<0.05$ was considered to indicate a significant difference between values.

\section{Results}

Quantitative determination of three components of A. lappa extract. Each compound in the HPLC chromatogram was identified by comparing the retention times and ultraviolet 


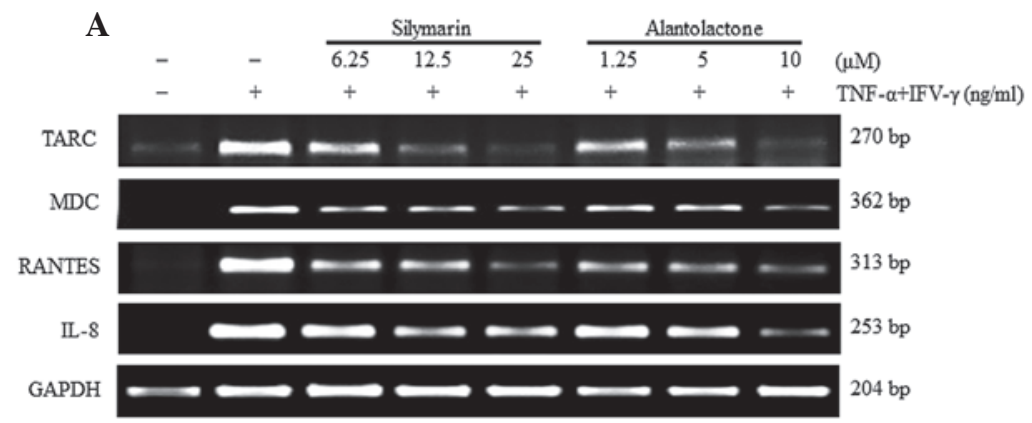

B
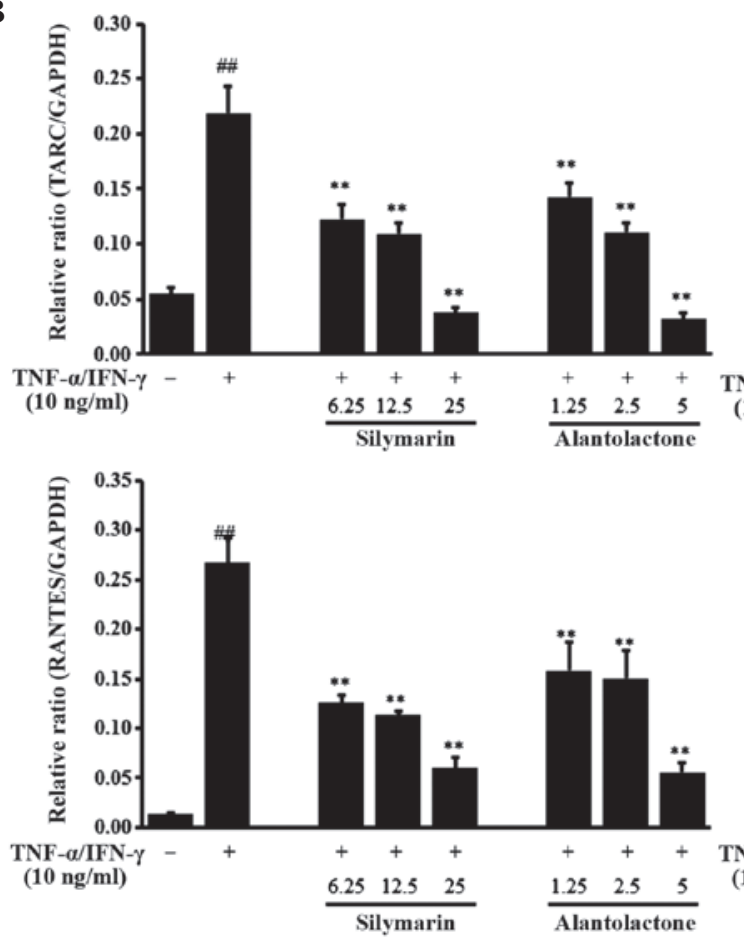
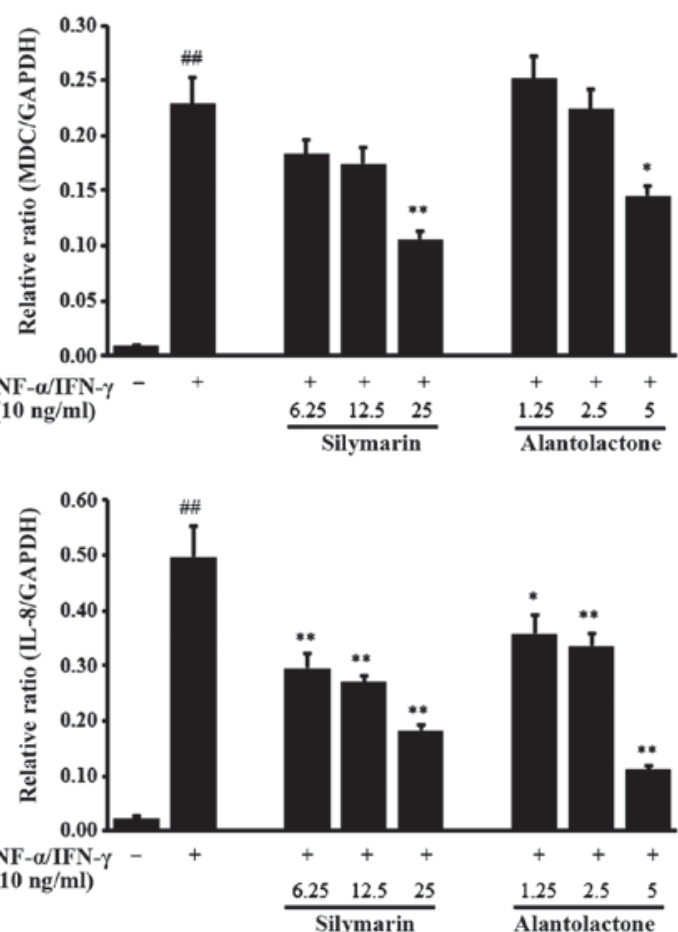

Figure 5. Effect of alantolactone on TNF- $\alpha$ - and IFN- $\gamma$-stimulated expression of chemokine mRNA in HaCaT cells. (A) Reversetranscription PCR was performed to determine the mRNA levels of TARC, MDC, RANTES and IL-8. (B) Bar graphs representing the intensities of the PCR bands. Values are expressed as the mean \pm standard error of the mean of three independent experiments. ${ }^{* \#} \mathrm{P}<0.01$ vs. vehicle control cells; ${ }^{*} \mathrm{P}<0.05$ and ${ }^{* *} \mathrm{P}<0.01 \mathrm{vs}$. TNF- $\alpha$ - and IFN- $\gamma$-stimulated cells. PCR, polymerase chain reaction. IFN, interferon; TNF, tumor necrosis factor.

absorption spectra with those of the reference standards. The retention times of costunolide, dehydrocostus lactone and alantolactone under the optimized conditions were $7.81,8.70$ and $10.22 \mathrm{~min}$, respectively (Fig. 1). Each regression equation $(y=a x+b)$ was calculated based on the ratio of peak area $(y)$ and concentration $(x, \mu \mathrm{g} / \mathrm{ml})$ of costunolide, dehydrocostus lactone and alantolactone. Standard curves plotted for the three compounds showed high linearity, with $r^{2} \geq 0.9999$ in eight different concentration ranges tested. The established analytical HPLC method was applied for the simultaneous quantification of the three compounds in the methanolic extract of A. lappa. The amounts of costunolide, dehydrocostus lactone and alantolactone in the extract were 17.32, 28.26, and $0.01 \mathrm{mg} / \mathrm{g}$, respectively.

Cytotoxicity of A. lappa extract components. The present study assessed the cytotoxic effects of the three components of the A. lappa extract on HaCaT cells (Fig. 2). The non-toxic concentrations of the three components were determined to be 10,10 , and $5 \mu \mathrm{M}$ for costunolide, dehydrocostus lactone and alantolactone, respectively. Non-toxic concentrations (>90\% compared with the control) of the three components were applied in the biological assays.

Inhibitory effects of costunolide, dehydrocostus lactone and alantolactone on the chemokine mRNA levels in TNF- $\alpha$-and IFN- $\gamma$-stimulated HaCaT cells. The effects of the three components of A. lappa extract on mRNA levels of the Thelper cell type 2 cytokines TARC, MDC, RANTES and IL-8 were assessed in TNF- $\alpha$ and IFN- $\gamma$-stimulated HaCaT cells. Stimulation with TNF- $\alpha$ and IFN- $\gamma$ significantly increased the expression of TARC, MDC, RANTES and IL- 8 mRNA in HaCaT cells (Figs. 3-5). Treatment of the cells with compound costunolide (Fig. 3), dehydrocostus lactone (Fig. 4) and alantolactone (Fig. 5) significantly reduced the expression of TARC, MDC, RANTES and IL-8 mRNA in a dose-dependent manner. Silymarin, a positive control, decreased the expression of TARC, MDC, RANTES and IL-8 mRNA compared with that following stimulation with TNF- $\alpha$ and IFN- $\gamma$ in a dose-dependent manner. 


\section{Discussion}

Chemokines have a pivotal role in immune responses and inflammatory reactions. Various inflammatory cytokines stimulate the production of chemokines and specific inflammatory chemokines are found in the serum of patients with atopic dermatitis (17). Among them, TARC/CCL17, MDC/CCL22 and RANTES/CCL5 are typical inflammatory chemokines that are predominantly expressed in various immune cells, including lymphocytes, dendritic cells, keratinocytes and eosinophils (18). Previous studies showed that levels of these chemokines in serum and skin lesions of patients with atopic dermatitis are elevated, suggesting that chemokines produced by keratinocytes may be key molecules that attract inflammatory lymphocytes to the skin (19). IL-8 is another important mediator in atopic dermatitis and previous studies have demonstrated that the amount of IL-8 is closely associated with the severity of atopic skin lesions (20).

The present study investigated the inhibitory effects of three components of A. lappa, including costunolide, dehydrocostus lactone and alantolactone on chemokine expression at the mRNA level in TNF- $\alpha$ and IFN- $\gamma$-stimulated HaCaT cells. All three sesquiterpene lactones markedly reduced TNF- $\alpha$ and IFN- $\gamma$-induced expression of TARC, MDC and IL-8 in a dose-dependent manner. While costunolide and dehydrocostus lactone had weak inhibitory effects on RANTES expression, alantolactone markedly suppressed the mRNA expression of RANTES mRNA in TNF- $\alpha$ and IFN- $\gamma$-stimulated HaCaT cells. These results indicated that these three components of A. lappa may have activity against skin inflammation through regulation of chemokine expression in keratinocytes.

Several studies have demonstrated the anti-inflammatory actions of sesquiterpene lactones from medicinal herbs, includings Milleria quinqueflora (21), Tithonia diversifolia (22), Ixeris dentate (23) and Eupatorium perfoliatum (24), suggesting potential use of these herbs as anti-inflammatory agents. Similarly, the present study reported the anti-inflammatory effects of sesquiterpene lactones from A. lappa. Further investigation is necessary to verify the results of the present study and to evaluate the suitability of sesquiterpene lactones from A. lappa for the treatment of skin inflammation, including atopic dermatitis.

In conclusion, the present study demonstrated that the costunolide, dehydrocostus lactone and alantolactone, components of A. lappa, reduced the mRNA expression levels of chemokines TARC, MDC, RANTES and IL- 8 in TNF- $\alpha$ and IFN- $\gamma$-stimulated HaCaT cells. These results indicated that the three compounds may be the active components of A. lappa that inhibit the production of chemokines. Further investigation is required to elucidate the detailed mechanisms of action of the sesquiterpene lactones, and the compounds should be subjected to toxicological tests using an in vivo experimental model.

\section{Acknowledgements}

The present study was supported by a grant from the Korea Institute of Oriental Medicine (Daejeon, Republic of Korea; no. K14030).

\section{References}

1. Korea Food and Drug Administration: The Korean herbal pharmacopoeia. Dongwon Munhwasa Seoul pp132, 2007.

2. Kim H, Kang K, Choi G, Kim H, Jeong S and Ju Y: A study on external and internal morphology and pattern analysis in 4 kinds of Mok-Hyaeng Radix. Korean J Oriental Med 12: 117-130, 2006.

3. Yoon TS, Sung YY, Jang JY, Yang WK, Ji Y and Kim HK Anti-obesity activity of extract from Saussurea lappa. Korean J Medicinal Crop Sci 18: 151-156, 2010.

4. Hasson SS, Al-Balushi MS, Alharthy K, Al-Busaidi JZ, Aldaihani MS, Othman MS, Said EA, Habal O, Sallam TA, Aljabri AA and Ahmedidris M: Evaluation of anti-resistant activity of Auklandia (Saussurea lappa) root against some human pathogens. Asian Pac J Trop Biomed 3: 557-562, 2013.

5. Choi JY, Na M, Hyun Hwang I, Ho Lee S, Young Bae E, Yeon Kim B and Seog Ahn J: Isolation of betulinic acid, its methyl ester and guaiane sesquiterpenoids with protein tyrosine phosphatase 1B inhibitory activity from the roots of Saussurea lappa C.B.Clarke. Molecules 14: 266-272, 2009.

6. Saleem TS, Lokanath N, Prasanthi A, Madhavi M, Mallika G and Vishnu MN: Aqueous extract of Saussurea lappa root ameliorate oxidative myocardial injury induced by isoproterenol in rats. J Adv Pharm Technol Res 4: 94-100, 2013.

7. Shah NC: Herbal folk medicines in Northern India. J Ethnopharmacol 6: 293-301, 1982.

8. Kim EJ, Hong JE, Lim SS, Kwon GT, Kim J, Kim JS, Lee KW and Park JH: The hexane extract of Saussurea lappa and its active principle, dehydrocostus lactone, inhibit prostate cancer cell migration. J Med Food 15: 24-32, 2012.

9. Chen HC, Chou CK, Lee SD, Wang JC and Yeh SF: Active compounds from Saussurea lappa Clarks that suppress hepatitis $B$ virus surface antigen gene expression in human hepatoma cells. Antiviral Res 27: 99-109, 1995.

10. Yaeesh S, Jamal Q, Shah AJ and Gilani AH: Antihepatotoxic activity of Saussurea lappa extract on D-galactosamine and lipopolysaccharide-induced hepatitis in mice. Phytother Res 24 (Suppl 2): S229-S232, 2010.

11. Lim HS, Ha H, Lee MY, Jin SE, Jeong SJ, Jeon WY, Shin NR, Sok DE and Shin HK: Saussurea lappa alleviates inflammatory chemokine production in $\mathrm{HaCaT}$ cells and house dust mite-induced atopic-like dermatitis in $\mathrm{Nc} / \mathrm{Nga}$ mice. Food Chem Toxicol 63: 212-220, 2014.

12. Rasul A, Khan M, Ali M, Li J and Li X: Targeting apoptosis pathways in cancer with alantolactone and isoalantolactone. Scientific World Journal 2013: 248532, 2013.

13. Ohnishi M, Yoshimi N, Kawamori T, Ino N, Hirose Y, Tanaka T, Yamahara J, Mirata $\mathrm{H}$ and Mori H: Inhibitory effects of dietary protocatechuic acid and costunolide on 7,12-dimethylbenz[a] anthracene-induced hamster cheek pouch carcinogenesis. Jpn J Cancer Res 88: 111-119, 1997.

14. Yoshikawa M, Hatakeyama S, Inoue $\mathrm{Y}$ and Yamahara J: Saussureamines A, B, C, D and E, new anti-ulcer principles from Chinese Saussureae Radix. Chem Pharm Bull (Tokyo) 41: 214-216, 1993.

15. Matsuda H, Kageura T, Inoue Y, Morikawa T and Yoshikawa M: Absolute stereostructures and syntheses of saussureamines A, B, $\mathrm{C}, \mathrm{D}$ and $\mathrm{E}$, amino acid-sesquiterpene conjugates with gastroprotective effect, from the roots of Saussurea lappa. Tetrahedron 56: 7763-7777, 2000

16. Kassuya CA, Cremoneze A, Barros LF, Simas AS, Lapa Fda R, Mello-Silva R, Stefanello ME and Zampronio AR: Antipyretic and anti-inflammatory properties of the ethanolic extract, dichloromethane fraction and costunolide from Magnolia ovata (Magnoliaceae). J Ethnopharmacol 124: 369-376, 2009.

17. Morita A, Kikuoka S, Korikawa T, Bito T, Yamada H, Kanda M, Sasakura K, Tamaki M, Hirai K, Suzuki R and Sugita K: Evaluation of human thymus and activation-regulated chemokine concentration in blood using a new sandwich EKISA based on monoclonal antibodies. Clin Chim Acta 322: 67-75, 2002.

18. Saeki $\mathrm{H}$ and Tamaki K: Thymus and activation regulated chemokine (TARC)/CCL17 and skin diseases. J Dermatol Sci 43: 75-84, 2006.

19. Pease JE: Targeting chemokine receptors in allergic disease. Biochem J 434: 11-24, 2011.

20. Casas C, Ribet V, Alvarez-Georges S, Sibaud V, Guerrero D, Schmitt AM and Redoules D: Modulation of interleukin-8 and staphylococcal flora by Avène hydrotherapy in patients suffering from chronic inflammatory dermatoses. J Eur Acad Dermatol Venereol 25 (Suppl 1): 19-23, 2011. 
21. Castro V, Rüngeler P, Murillo R, Hernandez E, Mora G, Pahl HL and Merfort I: Study of sesquiterpene lactones from Milleria quinqueflora on their anti-inflammatory activity using the transcription factor NF-kappaB as molecular target. Phytochemistry 53: 257-263, 2000.

22. Rüngeler P, Lyss G, Castro V, Mora G, Pahl HL and Merfort I: Study of three sesquiterpene lactones from Tithonia diversifolia on their anti-inflammatory activity using the transcription factor NF-kappaB and enzymes of the arachidonic acid pathway as targets. Planta Med 64: 588-593, 1998.
23. Kim SB, Kang OH, Joung DK, Mun SH, Seo YS, Cha MR, Ryu SY, Shin DW and Kwon DY: Anti-inflammatory effects of tectroside on UVB-induced HaCaT cells. Int J Mol Med 31: 1471-1476, 2013

24. Maas M, Deters AM and Hensel A: Anti-inflammatory activity of Eupatorium perfoliatum L. extracts, eupafolin, and dimeric guaianolide via iNOS inhibitory activity and modulation of inflammation-related cytokines and chemokines. J Ethnopharmacol 137: 371-381, 2011. 